\title{
Effects of Activated Bt Transgene Products (Cry1Ab, Cry3Bb) on Immature Stages of the Ladybird Adalia bipunctata in Laboratory Ecotoxicity Testing
}

\section{Journal Article}

Author(s):

Schmidt, Joerg E. U.; Braun, Cora U.; Whitehouse, Lisa P.; Hilbeck, Angelika

Publication date:

2009

Permanent link:

https://doi.org/10.3929/ethz-b-000114354

Rights / license:

In Copyright - Non-Commercial Use Permitted

Originally published in:

Archives of Environmental Contamination and Toxicology 56(2), https://doi.org/10.1007/s00244-008-9191-9 


\title{
Effects of Activated Bt Transgene Products (Cry1Ab, Cry3Bb) on Immature Stages of the Ladybird Adalia bipunctata in Laboratory Ecotoxicity Testing
}

\author{
Jörg E. U. Schmidt • Cora U. Braun • \\ Lisa P. Whitehouse · Angelika Hilbeck
}

Received: 22 January 2008 / Accepted: 16 June 2008/Published online: 20 August 2008

(C) Springer Science+Business Media, LLC 2008

\begin{abstract}
Insect-active Bacillus thuringiensis (Bt) proteins are expressed by several transgenic crop plants to control certain pests, but nontarget organisms such as ladybirds also can be exposed to these proteins in the field. We developed an improved ecotoxicity testing protocol and conducted feeding trials in a laboratory setting to test for possible adverse effects of different concentrations of microbially produced trypsin-activated $\mathrm{Cry} 1 \mathrm{Ab}$ and $\mathrm{Cry} 3 \mathrm{Bb}$ toxins on the coccinellid Adalia bipunctata. Larval/pupal mortality, development time, and overall body mass accumulation were recorded. Even at the lowest concentration $(5 \mu \mathrm{g} / \mathrm{ml})$, A. bipunctata larvae fed with the lepidopteran-active $\mathrm{Cry} 1 \mathrm{Ab}$ toxin exhibited significantly higher mortality than the control group. In experiments with the coleopteran-active $\mathrm{Cry} 3 \mathrm{Bb}$, only a concentration of $25 \mu \mathrm{g} / \mathrm{ml}$ resulted in a marginally significantly higher mortality compared to the control. Both experiments revealed a slight decline in mortality at the highest concentration of $50 \mu \mathrm{g} / \mathrm{ml}$, though this was statistically significant only in the Cry1 Ab treatment. No differences were detected for development time and body mass of newly emerged adults. Dilutions of the expression vector pBD10 — used as a control to exclude effects of the toxin
\end{abstract}

J. E. U. Schmidt · C. U. Braun · L. P. Whitehouse ·

A. Hilbeck

Institute of Integrative Biology, ETH Zurich, Zurich,

Switzerland

\author{
A. Hilbeck $(\square)$ \\ Department of Environmental Sciences, Institute of Integrative \\ Biology, ETH Zurich, Universitätstrasse 16, 8092 Zurich, \\ Switzerland \\ e-mail: angelika.hilbeck@env.ethz.ch
}

production method-at concentrations between 10 and 100 $\mu \mathrm{g} / \mathrm{ml}$ revealed no significant effects on either of the studied parameters. This suggests that the increased mortality of larvae in the toxin feeding trials was caused directly by the activated $\mathrm{Bt}$ toxins and raises questions regarding their commonly postulated specificity and their mode of action in A. bipunctata. Implications of the reported results for ladybird populations and their biological pest control functions in transgenic crop ecosystems are discussed.

Transgenic Bt plants expressing insect-active Cry toxins of the bacterium Bacillus thuringiensis $(\mathrm{Bt})$ were developed to control important agricultural pests. Two major transgenic insect-active crops, $\mathrm{Bt}$ maize and $\mathrm{Bt}$ cotton, are grown on an increasing area in several countries worldwide (James 2007). It is commonly postulated that Bt plants and their expression products, activated Bt toxins, are specifically efficacious against a limited number of target insects, while nontarget organisms, including pollinators and predacious arthropods, are not affected (e.g., Shelton et al. 2002; O'Callaghan et al. 2005). Studies with target species have identified a rather complex mode of action, which involves toxin receptors in their midgut cells (de Maagd et al. 2001; Whalon and Wingerd 2003).

Predators can encounter transgene products like plantexpressed Bt toxins when feeding on plant material, for example, pollen, nectar, or leaf exudates, and, additionally, when preying on other organisms that have consumed transgenic plant tissue or toxin-loaded prey (Harwood et al. 2005; Zwahlen and Andow 2005). Further, prey organisms that have ingested transgene products might not only pass the unchanged transgene product from the plant to the 
predator but also modify it by their own metabolism, potentially altering their biochemical activity and becoming more or less harmful to predators (Andow and Hilbeck 2004). Testing of predators for potential adverse effects of the expressed insect-active compounds in transgenic plants is, therefore, important considering their important biological control function as an ecosystem service. Several studies have investigated the effects of transgenic Bt plants on predaceous insects under laboratory conditions. In some cases, the tested species were significantly adversely affected (results that cannot be reliably predicted or explained yet), while in others no effects were observed (for more detail see reviews by Lövei and Arpaia 2005; O'Callaghan et al. 2005; Hilbeck and Schmidt 2006; Romeis et al. 2006).

Ladybirds represent abundant and highly valued biocontrol agents, particularly of aphids, mealy bugs, and mites (Obrycki and Kring 1998; Dixon 2000). Probably most, if not all, species also consume other insects and plant material, such as pollen (Lundgren et al. 2004, 2005). The two-spotted ladybird, Adalia bipunctata (L.), is an abundant polyphagous coccinellid species in many ecosystems in Europe (Hodek and Honěk 1996; Omkar and Pervez 2005). It has often been used for ecotoxicological studies with pesticides and was, therefore, selected for this study as a test species with regard to the risk assessment of transgenic crop plants in Europe.

Laboratory ecotoxicity testing forms a core part of the environmental risk assessment (ERA) of Bt plants prior to their commercial release. Standard protocols adopted from testing chemical environmental stressors (like pesticides), as outlined in guidance documents issued by national regulatory agencies and international organizations (USEPA, OECD), are typically used as the scientific basis for testing transgenic insecticidal plants for regulatory purposes. (Mendelsohn et al. 2003; Andow and Hilbeck 2004). While this approach to risk assessment has attracted criticism with regard to the applied protocols stemming largely from the ecotoxicity testing schemes of chemicals (Andow and Hilbeck 2004; Andow et al. 2006; Lang et al. 2007), this type of testing currently still constitutes the main part of nontarget testing in transgenic plants. Therefore, we aimed at improving the existing protocols by using activated toxins, which is what transgenic plants are supposed to produce, and larvae of nontarget organisms instead of adults, as those are supposed to be more susceptible.

In this study, we investigated possible adverse effects of two activated Bt proteins (Cry1 Ab, Cry3Bb), which are expressed, for instance, by several commercial transgenic Bt maize lines (Zea mays, e.g., MON810 or MON863), on the preimaginal development of A. bipunctata. Both toxins target different groups of pest species: Cry $1 \mathrm{Ab}$ is most efficacious against lepidopteran caterpillars, while $\mathrm{Cry} 3 \mathrm{Bb}$ is most active against certain herbivorous coleopteran larvae. As part of an integrated environmental risk assessment, these experiments are intended to provide initial information on possible hazards of these transgene products.

\section{Materials and Methods}

\section{Test Dilutions}

Stock solutions of all substances tested were provided by Plant Research International, Wageningen, The Netherlands. Bt protoxins (Cry1 Ab and $\mathrm{Cry} 3 \mathrm{Bb}$ ) were cloned in $E$. coli using Cry protein expression vectors based on the plasmid pBD10 (containing either the $c r y l A b$ gene or the $c r y 3 B b$ gene), solubilized, and trypsin-activated as described by Bosch et al. (1994). To exclude any effects caused by this microbial production process, feeding trials were also performed with solutions from pBD10; pBD10 is the so-called "empty expression vector cassette" without the cry genes. Toxin stock solutions were diluted in deionized water to concentrations of 5,25 , and $50 \mu \mathrm{g} / \mathrm{ml}$, respectively, and pBD10 stock solutions to concentrations of 10 , 50 , and $100 \mu \mathrm{g} / \mathrm{ml}$. The wider range and higher maximum of concentrations employed for $\mathrm{pBD} 10$ were chosen to test for its effects at very high doses compared to the toxins. Dilutions were tested for the presence of toxins using ImmunoStrips (Agdia, Elkhart, IN, USA) and stored at a temperature of $4^{\circ} \mathrm{C}$ during the course of the experiment. As a control treatment for all experimental series, we applied a buffer $(50 \mathrm{mM} \mathrm{NaHCO} 3, \mathrm{pH} 10,100 \mathrm{mM} \mathrm{NaCl})$, which had also been used for the production of the stock solutions. At the beginning of each repetition, dilutions and control solutions were filled separately into brown glass vials $(25 \mathrm{ml})$ with a spray-head and stored at a temperature of $4^{\circ} \mathrm{C}$.

\section{Insects}

All individuals of $A$. bipunctata used in the experiments originated from synchronously laid egg masses purchased from Andermatt Biocontrol, Grossdietwil, Switzerland. Upon arrival, egg masses were immediately transferred into transparent plastic petri dishes $(110 \mathrm{~mm}$ in diameter $)$ with round filter paper on the bottom and incubated under controlled environmental conditions $\left(25 \pm 1.5^{\circ} \mathrm{C}\right.$ temperature, $70 \% \pm 5 \%$ relative humidity, and a photoperiod of 16:8 $\mathrm{h}[\mathrm{L}: \mathrm{D}])$. No food was offered to the neonate larvae before the start of the experiment, but they were allowed to feed on each other or on unemerged Adalia eggs for $<24 \mathrm{~h}$. Cannibalism appears to be important for successful larval development in many ladybird species (Agarwala and Dixon 1992). 


\section{Experimental Setup}

Transparent plastic petri dishes were prepared as experimental containers for A. bipunctata larvae by cutting holes in the center of the lids to allow constant airflow and covering them with fine mesh to prevent the larvae from escaping.

As a food source for the ladybird larvae, which could easily be prepared with the test substances, we used sterilized eggs of the flour moth, Ephestia kuehniella Zeller (Lepidoptera: Pyralidae), purchased from Andermatt Biocontrol, Grossdietwil, Switzerland. E. kuehniella eggs were considered a high-quality food for coccinellids, including A. bipunctata larvae compared to aphids (Lanzoni et al. 2004; De Clerq et al. 2005). In each replicate, about 30-50 mg of Ephestia eggs (depending on the age of the ladybird larva in order to provide food on an ad libitum basis) was applied with a paintbrush to a small square of plain cardboard (ca. $33 \times 33 \mathrm{~mm}$ ). The eggs were sprayed with the respective treatment dilution and the cardboard was placed on a round filter paper on the bottom of the petri dish. A single ladybird larva (ca. $24 \mathrm{~h}$ ) was placed into each prepared petri dish using a moist soft paintbrush. To prevent larvae from escaping, all petri dishes were sealed with strips of parafilm along the margin.

The experiments were performed with 30 individual replicates of each concentration of Cry1Ab, Cry3Bb, or pBD10 and independently repeated four times. In each repetition, ladybird larvae from different shipments were used. The same environmental conditions $\left(25 \pm 1.5^{\circ} \mathrm{C}\right.$ temperature, $70 \% \pm 5 \%$ relative humidity, and a photoperiod of 16:8 h [L:D]) were applied throughout. Every second day throughout the larval development, mortality and developmental stage of all larvae were recorded and cardboards with sprayed Ephestia eggs were renewed. Fourth-instar larvae were checked for pupation every day. After pupation, cardboards were removed and the pupae were checked for emergence of adults every day. Newly emerged adults were weighed on a precision balance (Mettler Toledo AG 104; readability, $0.1 \mathrm{mg}$ ) after emergence as soon as their elytra had thoroughly hardened.

\section{Statistical Data Analysis}

Each of the three experiments (with Cry $1 \mathrm{Ab}, \mathrm{Cry} 3 \mathrm{Bb}$, and pBD10, respectively) was analyzed separately for each recorded parameter: total mortality, total preimaginal development time (defined as time between hatching of the first larval stage from egg until emergence of the adult from pupa), and body mass of young adults after emergence (representing preimaginal accumulation in body mass).

Total mortality for each experiment was calculated as the percentage (rate) of all larvae which did not develop to the adult stage. Data sets on mortality in each of the four independent repetitions $(N=4)$ were analyzed using a contingency table analysis following a categorical model. In this model, independence between paired observations is tested with a likelihood ratio test. If this test detected significant independence within a data set, pairwise chi-square tests were used to evaluate differences between the single protein concentrations.

For preimaginal development time and body mass, we calculated the arithmetic means from the individual measurements of each protein concentration within each of the four independent repetitions to produce the data set for further analysis. Untransformed data of all data sets were then tested for normal distribution using a Shapiro-Wilk $W$ test (goodness of fit). If, according to the result of this test, a normal distribution applied to a data set, overall differences between the different concentrations were analyzed with a one-way analysis of variance (ANOVA). If, however, no normal distribution could be detected in a data set, we used the nonparametric Kruskal-Wallis $H$-test to analyze differences in the overall data set. Following the results of the Shapiro-Wilk $W$-tests, a Kruskal-Wallis $H$ test was applied only to analyze differences in the data set for total preimaginal development time of the experiment with pBD10, while all other analyses were conducted with an ANOVA. In all tests, the establishment of significance was based on a probability level of $p<0.05$. All statistical calculations were conducted with JMP software, version 5.0 (SAS Institute Inc. 2002).

\section{Results}

Total Preimaginal Mortality Rates

In the contingency table analysis of our feeding experiment with trypsin-activated Cry1 Ab toxin, the likelihood ratio test indicated a highly significant independence between paired observations in the data set of mean preimaginal mortality rates $\left(\chi^{2}=31.681\right.$; $\left.\mathrm{df}=3 ; p<0.0001\right)$. Mortality rates were significantly different between the control treatment (16.7\%; mean of the four independent repetitions) and all three concentrations of the toxin. We recorded an $11 \%$ higher preimaginal mortality compared to the control $\left(\chi^{2}=4.126\right.$; $\left.\mathrm{df}=1 ; p=0.0422\right)$ when larvae were fed with a concentration of $5 \mu \mathrm{g} / \mathrm{ml}$. Mortality increased by more than $30 \%$ compared to the control when larvae were fed with a concentration of $25 \mu \mathrm{g} / \mathrm{ml}\left(\chi^{2}=\right.$ 29.665 ; df $=1 ; p<0.0001)$ and by a little less than $20 \%$ compared to the control $\left(\chi^{2}=11.591 ; \quad\right.$ df $=1$; $p=0.0007)$ when larvae were fed with a concentration of $50 \mu \mathrm{g} / \mathrm{ml}$ throughout their entire development (Table 1). Further, compared to the treatments with $5 \mu \mathrm{g} / \mathrm{ml}$, mortality 
Table 1 Mean mortality rates $(\%)$ of individual preimaginal stages of Adalia bipunctata in laboratory feeding experiments conducted with different concentrations of Cry1 Ab, Cry3Bb, and pBD10

\begin{tabular}{|c|c|c|c|c|c|c|c|c|c|c|}
\hline \multirow[t]{3}{*}{ Experiment } & \multirow{3}{*}{$\begin{array}{l}\text { Sprayed } \\
\text { substance }\end{array}$} & \multirow[t]{3}{*}{ Concentration } & \multicolumn{8}{|c|}{ Mortality (\%) } \\
\hline & & & \multirow[t]{2}{*}{$n$} & \multicolumn{5}{|c|}{ Larval stage } & \multirow[t]{2}{*}{ Pupa } & \multirow[t]{2}{*}{ Total* } \\
\hline & & & & $1 \mathrm{st}$ & 2 nd & $3 \mathrm{rd}$ & 4 th & Total & & \\
\hline \multirow[t]{4}{*}{$\mathrm{a}$} & \multirow[t]{4}{*}{ Cry1Ab } & $0 \mu \mathrm{g} / \mathrm{ml}(\mathrm{ctrl})$ & 120 & 14.2 & 1.0 & 1.0 & 0.0 & 15.8 & 1.0 & $16.7^{\mathrm{c}}$ \\
\hline & & $5 \mu \mathrm{g} / \mathrm{ml}$ & 120 & 24.2 & 3.3 & 0.0 & 0.0 & 26.7 & 1.1 & $27.5^{\mathrm{b}}$ \\
\hline & & $25 \mu \mathrm{g} / \mathrm{ml}$ & 120 & 44.2 & 3.0 & 1.5 & 3.1 & 48.3 & 1.6 & $49.2^{\mathrm{a}}$ \\
\hline & & $50 \mu \mathrm{g} / \mathrm{ml}$ & 120 & 31.7 & 4.9 & 1.3 & 0.0 & 35.8 & 0.0 & $35.8^{\mathrm{b}}$ \\
\hline \multirow[t]{4}{*}{$\mathrm{b}$} & \multirow[t]{4}{*}{ Cry3Bb } & $0 \mu \mathrm{g} / \mathrm{ml}(\mathrm{ctrl})$ & 120 & 20.8 & 1.1 & 0.0 & 0.0 & 21.7 & 0.0 & $21.7^{\mathrm{b}}$ \\
\hline & & $5 \mu \mathrm{g} / \mathrm{ml}$ & 120 & 15.8 & 5.0 & 2.1 & 0.0 & 21.7 & 0.0 & $21.7^{\mathrm{b}}$ \\
\hline & & $25 \mu \mathrm{g} / \mathrm{ml}$ & 120 & 24.2 & 5.5 & 4.7 & 1.2 & 32.5 & 1.2 & $33.3^{\mathrm{a}}$ \\
\hline & & $50 \mu \mathrm{g} / \mathrm{ml}$ & 120 & 25.8 & 3.4 & 2.3 & 0.0 & 30.0 & 1.2 & $30.8^{\mathrm{ab}}$ \\
\hline \multirow[t]{4}{*}{$\mathrm{c}$} & \multirow[t]{4}{*}{ pBD10 } & $0 \mu \mathrm{g} / \mathrm{ml}(\mathrm{ctrl})$ & 120 & 7.5 & 0.9 & 0.9 & 1.9 & 10.8 & 3.7 & $14.2^{\mathrm{a}}$ \\
\hline & & $10 \mu \mathrm{g} / \mathrm{ml}$ & 120 & 10.0 & 1.9 & 1.9 & 2.0 & 15.0 & 0.9 & $15.8^{\mathrm{a}}$ \\
\hline & & $50 \mu \mathrm{g} / \mathrm{ml}$ & 120 & 9.2 & 0.9 & 3.7 & 0.0 & 13.3 & 2.0 & $15.0^{\mathrm{a}}$ \\
\hline & & $100 \mu \mathrm{g} / \mathrm{ml}$ & 120 & 9.2 & 0.0 & 1.9 & 0.0 & 10.8 & 3.7 & $14.2^{\mathrm{a}}$ \\
\hline
\end{tabular}

Note: ctrl, control. $n$, number of tested individuals. * Values with different superscript letters are significantly different at a level of $p<0.05$ within the same experiment

rates were significantly higher in the treatments with $25 \mu \mathrm{g}$ / $\mathrm{ml}\left(\chi^{2}=12.040 ;\right.$ df $\left.=1 ; p=0.0005\right)$ but not in the treatments with $50 \mu \mathrm{g} / \mathrm{ml} \quad\left(\chi^{2}=1.930 ; \quad\right.$ df $=1$; $p=0.1648)$. Preimaginal mortality was significantly different for Cry $1 \mathrm{Ab}$ concentrations of 25 versus $50 \mu \mathrm{g} / \mathrm{ml}$ $\left(\chi^{2}=4.379 ;\right.$ df $\left.=1 ; p=0.0364\right)$.

For the feeding experiment with Cry $3 \mathrm{Bb}$, the likelihood ratio test revealed a nearly significant result $\left(\chi^{2}=6.830 ; \mathrm{df}=\right.$ $3 ; p=0.0775)$. Pairwise chi-square tests were performed to avoid ignoring marginally significant differences between one of the tested concentrations and the control. Within the data set, the total mean mortality rates of $A$. bipunctata preimaginal stages were significantly different between the treatment with a toxin concentration of $25 \mu \mathrm{g} / \mathrm{ml}$ and the control $\left(33.3 \% ; \chi^{2}=4.120 ; \mathrm{df}=1 ; p=0.0424\right)$. The control and a concentration of $5 \mu \mathrm{g} / \mathrm{ml}$ revealed an identical value for this parameter ( $21.7 \%$ mortality). At a concentration of 50 $\mu \mathrm{g} / \mathrm{ml}$, mortality was not significantly different $\left(30.8 \% ; \chi^{2}=\right.$ $2.615 ;$ df $=1 ; p=0.1059$ ) compared to the control (Table 1). Also, mortality at a toxin concentration of $50 \mu \mathrm{g} /$ $\mathrm{ml}$ was not significantly different from that at toxin concentrations of $5 \mu \mathrm{g} / \mathrm{ml}\left(\chi^{2}=2.615 ; \mathrm{df}=1 ; p=0.1059\right)$ and of $25 \mu \mathrm{g} / \mathrm{ml}\left(\chi^{2}=0.172 ; \mathrm{df}=1 ; p=0.6782\right)$.

No independence of paired observations could be detected in the experiment with $\mathrm{pBD} 10\left(\chi^{2}=0.181 ; \mathrm{df}=3\right.$; $p=0.9806)$. Here, total mean mortality rates were not significantly different between the control treatment $(14.2 \%)$ and either one of the three different concentrations (10 $\mu \mathrm{g} / \mathrm{ml}, 15.8 \% ; 50 \mu \mathrm{g} / \mathrm{ml}, 15.0 \% ; 100 \mu \mathrm{g} / \mathrm{ml}, 14.2 \%$; Table 1).
Total Preimaginal Development Time and Body Mass of Newly Emerged Adults

No statistically significant differences in the total preimaginal development times of $A$. bipunctata (between hatching of the first larval stage from egg and emergence of adult beetles; ANOVA, $F=0.587$, df $=3, p=0.6350$ ) were documented between the control treatment and any of the three concentrations of the activated Bt toxin Cry1Ab (Table 2). Values ranged between 15.7 and 16.6 days. Similarly, there were also no statistically significant differences in the total preimaginal development times $(F=2.249 ; \mathrm{df}=3 ; p=0.1350)$ between the control and any of the three different concentrations of Cry3Bb toxin. Values varied from $15.8 \pm 0.1$ days in the control to $16.2 \pm$ 0.2 days in the treatment with a concentration of $25 \mu \mathrm{g} / \mathrm{ml}$. Also, no statistically significant differences (KruskalWallis $H$-test: $H=0.975$; df $=3 ; p=0.8073$ ) were documented in the data sets for individuals fed with different concentrations of pBD10.

Body mass of newly emerged adults was not significantly different (ANOVA: $F=0.877$; df $=3 ; p=0.4802$; Table 2). Mean body mass of adults was not significantly different between the control treatment and the three Cry3Bb toxin concentrations applied to their larval food (ANOVA: $F=1.226$; df $=3 ; p=0.3429$ ). Also, no statistically significant differences were observed between the three concentrations of $\mathrm{pBD} 10$ and the respective control treatment (ANOVA: $F=0.102 ;$ df $=3$; $p=0.9574)$. 


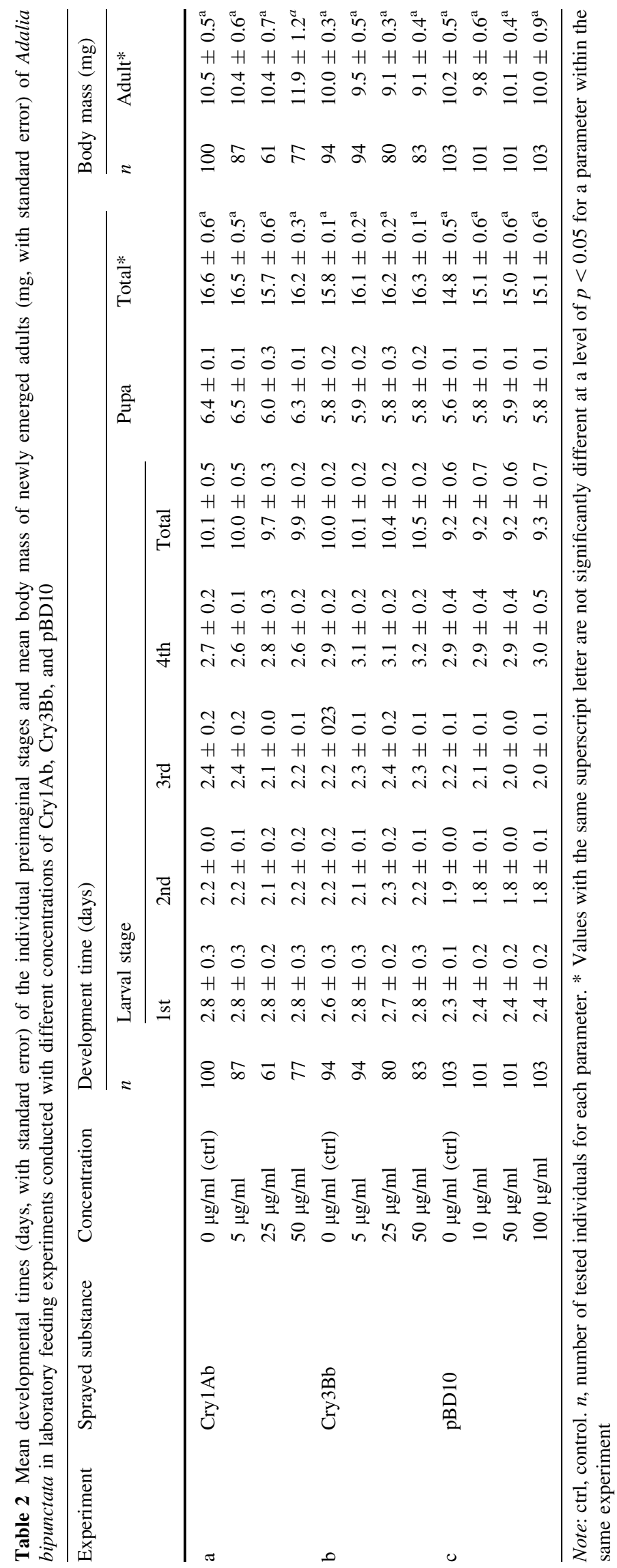




\section{Discussion}

Based on the common knowledge of the mode of action and the efficacy of the two tested Bt toxins to certain groups of target species, Lepidoptera or herbivorous Coleoptera larvae, it would not be expected that a predacious coleopteran nontarget species exhibits susceptibility to the lepidopteranactive protein Cry1Ab. However, the increased preimaginal mortality rates in our laboratory feeding trials suggest a direct toxic effect of Cry $1 \mathrm{Ab}$ and, to a much lesser extent, of the coleopteran-active $\mathrm{Cry} 3 \mathrm{Bb}$ in their trypsin-activated form to the predator A. bipunctata under the experimental conditions applied. A further unexpected finding is the slight decline in preimaginal mortality at the highest concentrations $(50 \mu \mathrm{g} / \mathrm{ml})$ of both toxins compared to the medium concentrations used in our experiment $(25 \mu \mathrm{g} / \mathrm{ml})$. This observation suggests the lack of a typical doseresponse relationship in the studied system.

The highest mortality occurred during the early larval stages (Table 1). Affected individuals died quickly, without long times of sickness, and surviving individuals did not show longer development times or lower body mass values than controls. While this suggests that sublethal effects do not exist with regard to these parameters, effects on other parameters (e.g., fecundity, longevity) cannot be excluded and should be investigated in additional studies. Although we observed no indication of a feeding deterrent behavior, this aspect should be given attention, as reduced feeding and decreased food utilization could also impose a higher mortality, which has been reported from herbivores (Deml et al. 1999; Hussein et al. 2005). On the other hand, toxin concentrations should be quantified throughout the course of feeding experiments to ensure that degradation of toxins is not responsible for the lack of mortality in later larval stages.

To explain our observations, we consider that additional studies on the mode of action in nontarget species are necessary, including histological and molecular aspects (Hilbeck and Schmidt 2006). As even in target pests the mode of action of Bt toxins is not fully understood and new aspects are still being discovered (Crickmore 2005), the sum of unexplained effects observed here might indicate a different mode of action of the $\mathrm{Bt}$ toxin in predacious arthropods, and other nontarget organisms as well. In a recent paper, interactions of $\mathrm{Bt}$ toxins and the community of midgut bacteria were suggested to play a key role in $\mathrm{Bt}$ toxicity (Broderick et al. 2006). Such indications should be followed scientifically also in the light of other recent studies reporting unexpected effects (Rosi-Marshall et al. 2007; Bøhn et al 2008). Further, genetically determined differences in the sensitivity of nontarget test organisms cannot be ruled out to explain our findings. Such differences might lead to a lethal response in one genotype and the lack of a recognizable response in the other. Systematic studies with different genotypes of predators should be conducted to test this hypothesis.

Initial experiments, like the ones conducted in this study, provide important data on toxicological responses of nontarget organisms to Bt toxins. Nonetheless, they cannot simply be extrapolated to describe the potential ecological impacts of Cry proteins in the field, but have to be complemented with experiments under ecologically more realistic conditions (Lang et al. 2007).

To assess the ecological relevance of such a study and the risk that a given nontarget species encounters in the field, it is important to consider whether this species can be exposed to harmful transgene products in similar concentrations. A. bipunctata is a polyphagous ladybird which consumes a range of different aphid species, but their suitability as prey differs from species to species. The use of coccids and diaspids as alternative prey was also reported as well as the consumption of pollen in the absence of aphids (Omkar and Pervez 2005). Under laboratory conditions, aphids feeding on Cry1 Ab-expressing maize (event Bt11) were shown not to incorporate the $\mathrm{Bt}$ toxin (Table 3), because it is, apparently, not transported in the phloem of these plants (Raps et al. 2001; Dutton et al. 2002). Exposure of ladybirds to Bt toxins in Cry1 Ab maize fields is, therefore, rather unlikely as long as they feed solely on aphids. For other plants, especially dicotyledonous crops, it is not known whether phloem sap does contain

Table 3 Amount of Bt toxin in potential food sources of ladybirds from transgenic maize crop ecosystems

\begin{tabular}{lllll}
\hline Food source & $\begin{array}{l}\text { Transgenic } \\
\text { expression product }\end{array}$ & Event & Toxin level & Reference \\
\hline Pollen & Cry1 Ab & Bt176 & $1.1-2.3 \mu \mathrm{g} / \mathrm{g} \mathrm{fw}$ & AGBIOS (2008) \\
& & MON810 & $7.9-10.3 \mu \mathrm{g} / \mathrm{g} \mathrm{fw}$ & AGBIOS (2008) \\
& Cry3Bb & MON863 & $10-81 \mu \mathrm{g} / \mathrm{g} \mathrm{fw}$ & AGBIOS (2008) \\
& & & $34.7-101.0 \mu \mathrm{g} / \mathrm{g}$ fw & Duan et al. (2002) \\
& & MON88017 & $25 \mu \mathrm{g} / \mathrm{g} \mathrm{dw}$ & Canadian Food Inspection Agency (2006) \\
Rhopalosiphum padi (aphid) & Cry1Ab & Bt11 & $<0.001 \mu \mathrm{g} / \mathrm{g} \mathrm{fw}$ & Dutton et al. (2005) \\
\hline
\end{tabular}

Note: fw, fresh weight; $\mathrm{dw}$, dry weight 
Bt toxins, but Cry proteins were found in low-concentration (4-6 ng/g fresh weight) in cotton aphids, Aphis gossypii Glover, and can be transferred into aphid-based food chains including ladybirds (Zhang et al. 2004, 2006). Contents of Cry3 toxins in aphids have not been studied to date.

Ladybird larvae and adults also consume plant material in the form of pollen, often to overcome food shortages (Lundgren et al. 2005). By feeding on pollen of transgenic Bt plants, larvae are indeed exposed to transgene products expressed by the plants. Amounts of Bt toxins in pollen can vary considerably between different transgenic maize lines and also within the same line, with values exceeding the toxin concentrations tested in this study, e.g., in Cry3Bbexpressing MON863 (Table 3). Duan et al. (2002) and Lundgren and Wiedenmann (2002), however, found no significant adverse effects of pollen from MON863 maize fed to larvae of the ladybird Coleomegilla maculata DeGeer, which could be in agreement with our finding that A. bipunctata larvae exhibited a lower susceptibility to $\mathrm{Cry} 3 \mathrm{Bb}$ toxin than to Cry1 Ab.

Consumption of alternative insect prey, which have ingested transgene products from plants, might also expose ladybirds to Bt toxins. Different species of herbivores and predators in Cry $1 \mathrm{Ab}$ maize fields were found to incorporate the toxin at concentrations up to $2.59 \mu \mathrm{g} / \mathrm{g}$, and also adult ladybirds of North American species in Cry1 Ab maize fields were shown to contain low amounts of Cry1 Ab, ranging from 0.2 to $1.3 \mu \mathrm{g} / \mathrm{g}$ (Harwood et al. 2005, 2007). Also, no published data exist on Cry 3 toxin concentrations in arthropods. As the food choice of predators can change considerably from year to year in the same crop (Schmidt 2006), the uptake of Bt toxins from different food sources might also be different over time. To date, few studies have been published regarding the possible accumulation of $\mathrm{Bt}$ toxins in food webs. While some literature implies that $\mathrm{Bt}$ toxins do not accumulate in food webs (Harwood et al. 2005), Obrist et al. (2006) reported fluctuating concentrations in spider mites, Tetranychus urticae Koch (Acarina: Tetranychidae), that occasionally were three times higher than in maize leaves they had fed on. Zhang et al. (2006) found $\mathrm{Bt}$ concentrations in a ladybird to be higher than in its aphid prey. Thus, it cannot be excluded that ladybird larvae can be exposed to potentially hazardous concentrations of $\mathrm{Cry} 1 \mathrm{Ab}$ or $\mathrm{Cry} 3 \mathrm{Bb}$, particularly when transgenic plants are cultivated extensively and for longer periods of time.

Acknowledgments This study was financed by the fifth framework program of the European Commission (project Bt-BioNoTa, QLK3CT-2000-00547). We thank Ruud A. de Maagd and Mieke WeemenHendriks, Plant Research International, Wageningen, The Netherlands, for producing the trypsin-activated toxin and pBD10 stock solutions. We are grateful to Peter J. Edwards, Salvatore Arpaia, and two anonymous reviewers for useful comments on early versions of the manuscript.

\section{References}

Agarwala BK, Dixon AFG (1992) Laboratory study on cannibalism and interspecific predation in ladybirds. Ecol Entomol 17:303309. doi:10.1111/j.1365-2311.1992.tb01062.x

AGBIOS (2008) GM Database. Information on GM approved products. Available at: http://www.agbios.com. Accessed January 6, 2008

Andow DA, Lövei GL, Arpaia S (2006) Ecological risk assessment for Bt crops. Nat Biotechnol 24:749-751. doi:10.1038/ nbt0706-749

Andow DA, Hilbeck A (2004) Science-based risk assessment for nontarget effects of transgenic crops. Bioscience 54:637-649. doi: 10.1641/0006-3568(2004)054[0637:SRAFNE]2.0.CO;2

Bøhn T, Primicerio R, Hessen DO, Traavik T (2008) Reduced fitness of Daphnia magna fed a Bt-transgenic maize variety. Arch Environ Toxicol Chem. doi: 10.1007/s00244-008-9150-5

Bosch D, Schipper B, van der Kleij H, de Maagd RA, Stiekema WJ (1994) Recombinant Bacillus thuringiensis crystal proteins with new properties: possibilities for resistance management. Bio/ Technology 12:915-918. doi:10.1038/nbt0994-915

Broderick NA, Raffa KF, Handelsman J (2006) Midgut bacteria required for Bacillus thuringiensis insecticidal activity. Proc Natl Acad Sci USA 103:15196-15199. doi:10.1073/pnas.0604865103

Canadian Food Inspection Agency (2006) Determination of the safety of Monsanto Canada Inc.'s glyphosate-tolerant, corn-rootwormprotected corn (Zea mays L.) event MON 88017. Decision document DD2006-57. Available at: http://www.agbios.com. Accessed January 6, 2008

Crickmore N (2005) Using worms to better understand how Bacillus thuringiensis kills insects. Trends Microbiol 13:347-350. doi: 10.1016/j.tim.2005.06.002

De Clercq P, Bonte M, Van Speybroeck K, Bolckmans K, Deforce K (2005) Development and reproduction of Adalia bipunctata (Coleoptera: Coccinellidae) on eggs of Ephestia kuehniella (Lepidoptera: Phycitidae) and pollen. Pest Manag Sci 61:11291132. doi:10.1002/ps.1111

de Maagd RA, Bravo A, Crickmore N (2001) How Bacillus thuringiensis has evolved specific toxins to colonize the insect world. Trends Genet 17:193-199. doi:10.1016/S0168-9525 (01)02237-5

Deml R, Meise T, Dettner K (1999) Effects of Bacillus thuringiensis $\delta$-endotoxins on food utilization, growth, and survival of selected phytophagous insects. J Appl Entomol 123:55-64. doi:10.1046/ j.1439-0418.1999.00312.x

Dixon AFG (2000) Insect predator-prey dynamics. Ladybird beetles \& biological control. Cambridge University Press, Cambridge

Duan JJ, Head G, McKee MJ, Nickson TE, Martin JW, Sayegh FS (2002) Evaluation of dietary effects of transgenic corn pollen expressing Cry3Bb1 protein on a non-target ladybird beetle, Coleomegilla maculata. Entomol Exp Appl 104:271-280. doi: 10.1023/A:1021258803866

Dutton A, Klein H, Romeis J, Bigler F (2002) Uptake of Bt-toxin by herbivores feeding on transgenic maize and consequences for the predator Chrysoperla carnea. Ecol Entomol 27:441-447. doi: 10.1046/j.1365-2311.2002.00436.x

Harwood JD, Wallin WG, Obrycki JJ (2005) Uptake of Bt endotoxins by nontarget herbivores and higher order arthropod predators: molecular evidence from a transgenic corn ecosystem. Mol Ecol 14:2815-2823. doi:10.1111/j.1365-294X.2005.02611.x

Harwood JD, Samson RA, Obrycki JJ (2007) Temporal detection of $\mathrm{Cry} 1 \mathrm{Ab}$ endotoxins in coccinellid predators from fields of Bacillus thuringiensis corn. Bull Entomol Res 97:642-648. doi: 10.1017/S000748530700524X

Hilbeck A, Schmidt JEU (2006) Another view on Bt proteins-How specific are they and what else might they do? Biopestic Int 2:1-50 
Hodek I, Honěk A (1996) Ecology of Coccinellidae. Kluwer Academic, Dordrecht

Hussein HM, Habuštová O, Sehnal F (2005) Beetle-specific Bacillus thuringiensis Cry3Aa toxin reduces larval growth and curbs reproduction in Spodoptera littoralis (Boisd.). Pest Manage Sci 61:1186-1192. doi:10.1002/ps.1112

James C (2007) Global status of commercialized biotech/GM crops: 2007. ISAAA Brief 37. International Service for the Acquisition of Agri-Biotech Applications, Ithaca, NY

Lang A, Lauber E, Darvas B (2007) Early-tier tests insufficient for GMO risk assessment. Nat Biotechnol 25:35-36. doi: 10.1038/nbt0107-35

Lanzoni A, Accinelli G, Bazzocchi GG, Burgio G (2004) Biological traits and life table of the exotic Harmonia axyridis compared with Hippodamia variegata, and Adalia bipunctata (Col., Coccinellidae). J Appl Entomol 128:298-306. doi:10.1111/ j.1439-0418.2004.00847.x

Lövei GL, Arpaia S (2005) The impact of transgenic plants on natural enemies: a critical review of laboratory studies. Entomol Exp Appl 114:1-14. doi:10.1111/j.0013-8703.2005.00235.x

Lundgren JG, Wiedenmann RN (2002) Coleopteran-specific Cry3Bb toxin from transgenic corn pollen does not affect the fitness of a nontarget species, Coleomegilla maculata DeGeer (Coleoptera: Coccinellidae). Environ Entomol 31:1213-1218

Lundgren JG, Razzak AA, Wiedenmann RN (2004) Population responses and food consumption by predators Coleomegilla maculata and Harmonia axyridis (Coleoptera: Coccinellidae) during anthesis in an Illinois cornfield. Environ Entomol 33:958963

Lundgren JG, Huber A, Wiedenmann RN (2005) Quantification of consumption of corn pollen by the predator Coleomegilla maculata (Coleoptera: Coccinellidae) during anthesis in an Illinois cornfield. Agr Forest Entomol 7:53-60. doi:10.1111/ j.1461-9555.2005.00246.x

Mendelsohn M, Kough J, Vaituzis Z, Matthews K (2003) Are Bt crops safe? Nat Biotechnol 9:1003-1009. doi:10.1038/nbt0903-1003

Obrist LB, Dutton A, Albajes R, Bigler F (2006) Exposure of arthropod predators to Cry1 Ab toxin in Bt maize fields. Ecol Entomol 31:143-154. doi:10.1111/j.0307-6946.2006.00762.x

Obrycki JJ, Kring TJ (1998) Predaceous Coccinellidae in biological control. Annu Rev Entomol 43:295-321. doi:10.1146/annurev. ento.43.1.295

O'Callaghan M, Glare TR, Burgess EPJ, Malone LA (2005) Effects of plants genetically modified for insect resistance on nontarget organisms. Annu Rev Entomol 50:271-292. doi:10.1146/annurev. ento.50.071803.130352

Omkar, Pervez A (2005) Ecology of two-spotted ladybird, Adalia bipunctata: a review. J Appl Entomol 129:465-474. doi: 10.1111/j.1439-0418.2005.00998.x

Raps A, Kehr J, Gugerli P, Moar WJ, Bigler F, Hilbeck A (2001) Immunological analysis of phloem sap of Bacillus thuringiensis corn and of the nontarget herbivore Rhopalosiphum padi (Homoptera: Aphididae) for the presence of Cry1Ab. Mol Ecol 10:525-533. doi:10.1046/j.1365-294x.2001.01236.x

Romeis J, Meissle M, Bigler F (2006) Transgenic crops expressing Bacillus thuringiensis toxins and biological control. Nat Biotechnol 24:63-71. doi:10.1038/nbt1180

Rosi-Marshall EJ, Tank JL, Royer TV, Whiles MR, Evans-White M, Chambers C, Griffiths NA, Pokelsek J, Stephen ML (2007) Toxins in transgenic crop byproducts may affect headwater stream ecosystems. Proc Natl Acad Sci USA 104:16204-16208. doi:10.1073/pnas.0707177104

SAS Institute Inc (2002) JMP user's guide, version 5. SAS Institute, Cary, NC

Schmidt JEU (2006) The influence of transgenic plants expressing Bacillus thuringiensis $\partial$-endotoxins on arthropod diversity and trophic interactions in crop ecosystems. Ph.D. dissertation. ETH, Zurich

Shelton AM, Zhao JZ, Roush RT (2002) Economic, ecological, food safety, and social consequences of the deployment of $\mathrm{Bt}$ transgenic plants. Ann Revu Entomol 47:845-881. doi: 10.1146/annurev.ento.47.091201.145309

Whalon ME, Wingerd BA (2003) Bt: mode of action and use. Arch Insect Biochem 54:200-211. doi:10.1002/arch.10117

Zhang GF, Wan FH, Guo JY, Hou ML (2004) Expression of Bt toxin in transgenic $\mathrm{Bt}$ cotton and its transmission through pests Helicoverpa armigera and Aphis gossypii to natural enemy Propylaea japonica in cotton plots. Acta Entomol Sinica 47:334-341

Zhang GF, Wan FH, Lövei GL, Liu WX, Guo JY (2006) Transmission of Bt toxin to the predator Propylaea japonica (Coleoptera: Coccinellidae) through its aphid prey feeding on transgenic $\mathrm{Bt}$ cotton. Environ Entomol 35:143-150. doi:10.1603/0046-225X (2006)35[1232:EABROD]2.0.CO;2

Zwahlen C, Andow DA (2005) Field evidence for the exposure of ground beetles to Cry $1 \mathrm{Ab}$ from transgenic corn. Environ Biosafe Res 4:1-5. doi:10.1051/ebr:2005014 